ZatącZnils

DOI 10.21697/zk.2020.7.18

\title{
TEKSTUALNOŚĆ PERFORMATYWNA, CZYLI METODOLOGIA BADAŃ LEGEND ARTYSTYCZNYCH ${ }^{1}$
}

Pawet Stangret

$$
\begin{aligned}
& \text { Wydział Nauk Humanistycznych UKSW } \\
& \text { Faculty of Humanities, } \\
& \text { Cardinal Stefan Wyszyński University in Warsaw } \\
& \text { p.stangret@uksw.edu.pl } \\
& \text { ORCID: 0000-0002-5162-4804 }
\end{aligned}
$$

Artysta legendarny - co oznacza to określenie? Czy to twórca najważniejszych, najbardziej wartościowych dzieł sztuki? Jakim kryterium to oceniać - czy chodzi o popularność, czy może o trwałość i rozległość recepcji? Może tę cechę przyznać autorowi najdonioślejszych koncepcji teoretycznych, twórcy nowych prądów, metod uprawiania sztuki itd.? A może legendami są skandaliści, oburzający i fascynujący jednocześnie niekonwencjonalnym sposobem bycia - w życiu prywatnym, jak również artystycznym? Dlaczego niektórzy twórcy stają się legendarni? Co i kto decyduje o tym statusie? Niniejszy artykuł koncentruje się przede wszystkim na metodzie służącej badaniu legend artystycznych, artystów jako tekstów kultury. Jakimi metodami możliwe jest odczytywanie legendy artystycznej? Metoda badawcza „artysty jako tekstu” związana jest z wieloma aspektami.

Na wstępie należy przybliżyć materiał, który będzie podstawą do analizy. Ten problem (różnie definiowany) bywał przedmiotem refleksji ${ }^{2}$, jednak ni-

1 Artykuł jest wynikiem badań finansowanych przez Narodowe Centrum Nauki w ramach projektu „Artysta jako tekst. Konstrukt tożsamościowy reżysera jako komentarz do działań teatralnych", nr UMO-2014/13/D/HS2/02842. Szerokie omówienie tematu artykułu zawarłem w mojej książce Artysta jako tekst. Nowoczesna sztuka metatekstu, Warszawa 2018.

2 Zob. D. Antonik, Autor jako marka. Literatura w kulturze audiowizualnej społeczeństwa informacyjnego, Kraków 2014; a także: M. Popiel, Świat artysty. Modernistyczne estetyki tworzenia, Kraków 2018. 
gdy całościowej i ujętej w karby metodologii badawczej. Głównym powodem takiej sytuacji było podejście egzocentryczne, niewpisujące osoby twórcy jako integralnego elementu dzieła sztuki. Na wstępie pierwsze zastrzeżenie: mowa o dziele sztuki nowoczesnej, ponieważ omawiana metoda służy do badania twórczości nowoczesnej, tzn. tej, dla której ukształtowała się konwencja komentarza jako relacji intertekstualnej dla artefaktu. Oczywiście, komentarz jest jednym $\mathrm{z}$ najstarszych gatunków literackich (np. ars poetica), jednak w sztuce nowoczesnej prezentowany jest on w mediach jako tekst pozaestetyczny (wywiad, post itd.) i jako taki wymaga od widza aktywności polegającej na włączeniu go do interpretacji dzieła.

Nowoczesne legendy artystyczne związane są ze zmianami w postrzeganiu twórcy w społeczeństwie. Artysta, w dużo większym stopniu niż sama sztuka, staje się istotny jako twór społeczny. Tutaj pojawia się główny paradoks nowoczesnej twórczości: z jednej bowiem strony awangardowe, jak również neoawangardowe i postawangardowe wystąpienia zmierzały do deprecjacji dzieła sztuki. Dadaistyczne hasła: „każdy jest artystą”, „sztuka jest w głowie" itp. powodowały, że artefakty przestały mieć materialną istotność. Z drugiej strony, rozwijał się nurt w sztuce, który dopuszczał niematerialne formy jako dzieło sztuki. Mam na myśli dadaistyczną (wraz $\mathrm{z}$ jej następstwami) antysztukę, której przykładem jest m.in. późniejsza sztuka konceptualna czy performance art.

Twórczość, w której brak materialności może być nośnikiem jakości artystycznych, swoje antecedencje ma, między innymi, w modernistycznej Wielkiej Reformie Teatru. To właśnie wtedy niematerialne formy - jak na przykład interpretacja - stały się nowym językiem twórczości. Z dzisiejszej perspektywy, kiedy efemeryczność teatru została zakwestionowana ${ }^{3}$, istotne jest, że poruszona została kwestia archiwum. Zgoda na postulowaną wówczas ,autonomię" teatru de facto zapoczątkowała konwencję, w której nową sztuką będzie dzieło istniejące jedynie w czasie jego prezentacji, a dokładnie - w czasie odbioru - i nie musi ono posiadać materialnej formy go utrwalającej. Zapoczątkowana została tendencja akcentująca sam gest artystyczny. Powstająca wtedy, nowocześnie rozumiana teatralność (jako niezależna od innych dziedzin artystycznych) była najlepszym dowodem na to, że nowe

3 D. Sajewska, Mit efemeryczności teatru, „Dialog” 2015, nr 1. 
rozumienie sztuki odchodzi od materialnej podstawy, od swojego pierwowzoru zapisanego i utrwalonego w postaci dramatu jako tekstu literackiego. Jednocześnie podkreślanie tych aspektów sztuki bardzo mocno zaznaczyło wartość procesu artystycznego - szeregu operacji intelektualnych, artystycznych - a przy tym znacznie rozbudowało sieć intertekstualną, w której zaczęło funkcjonować dzieło sztuki.

Równocześnie zmieniło się postrzeganie samego artysty. Walter Benjamin opisał zjawisko, które pozwala przenosić aurę z dzieła na jego autora ${ }^{4}$. Kwestionowanie materialności artefaktu - bądź programowo przez teorie awangardowe, bądź przez jego materialną wtórność (problem kopii opisywany przez Benjamina ${ }^{5}$ - doprowadziło do zwrócenia uwagi na samego twórcę. Artysta stał się interesujący dla publiczności jako twórca dzieła. Obcowanie z autorem stało się możliwością wejścia za kulisy artefaktu, dotarcia do procesu jego powstawania; dało także możliwość uchwycenia genezy „legendarnej” recepcji. Istotne są jeszcze dwa składniki: jednym z nich jest konstrukcja dzieła nowoczesnego, dzieła udziwnionego, programowo nastawionego na wysiłek odbiorcy koncentrujący się na odczytaniu czy odczytywaniu jego sensów. Drugim jest tendencja do komunikowania komentarza w mediach, których wykorzystywanie stawało się coraz bardziej popularne.

Trudne dzieła sztuki zaczęły wymagać autokomentarza. Problem „manifestomanii”, programowo niewystarczających dzieł, zrodził z jednej strony krytyków, którzy opowiadali się za trwałością, a przeciwko eksperymentowi, z drugiej zaś odbiorców, którzy doskonale umieli posługiwać się nowym językiem artystycznym - łączyli artefakt z komentarzem teoretycznym. W każdym razie dzieło wymagające komentarza autorskiego stało się konwencją, przede wszystkim konwencją odbiorczą. Dlaczego publiczność zaczęła potrzebować komentarza? Na to złożyło się kilka aspektów.

${ }^{4}$ W. Benjamin, Dzieło sztuki w dobie reprodukcji technicznej, [w:] idem, Anioł historii. Eseje, szkice, fragmenty, wyb. i oprac. H. Orłowski, tłum. K. Krzemieniowa, H. Orłowski, J. Sikorski, Poznań 1996. Benjamin wiąże to zjawisko z problematyką kopii i zanikiem oryginału w nowoczesnej sztuce (np. w filmie, fotografii, na płycie muzycznej).

5 Ibidem. 
Po pierwsze, nowa sztuka ${ }^{6}$ była tak oryginalna, że złączyła się naturalnie ze swoją eksplikacją, z komentarzem pomagającym dookreślić sensy a przynajmniej jawiący się jako możliwy do pełnienia tej pomocniczej funkcji. Po drugie, istnienie takiej konwencji twórczości pokazało, że odbiorcy nauczyli się poszukiwać sensów dzieła poza nim. Kolejnym aspektem jest sama postawa twórcza. Artyści zostali postawieni w sytuacji, w której mogą nie tyle dookreślić swoje dzieło, ile zwielokrotnić i skomplikować jego sensy. Ponadto stworzyło to okazję do sterowania recepcją, do dawania wskazówek interpretacyjnych, a to wiązało się z kolejnym (czwartym już) aspektem, jakim jest rozwój mediów. Dał on bowiem twórcom płaszczyznę, na której mogli komunikować autokomentarze, a coraz szerszy zasięg kultury medialnej doprowadził do sytuacji, w której twórca czuł się w obowiązku związać dzieło z procesem jego powstawania, a tym samym ze swoją osobą. Autor wypełnia w ten sposób konwencję komunikacyjną, sugeruje odbiorcy możliwość odczytywania dzieła poprzez autokomentarz i sensy w nim zawarte. Jednocześnie natura mediów sprawia, że autokomentarz staje się materialnie obszerniejszy od dzieła - jako się rzekło - trudnego do jednoznacznego odczytania.

Sztuka awangardowa od początku była atakowana za to, że nie poprzestaje jedynie na jakościach estetycznych. Artyści nowocześni chcieli pełnić nową funkcję w życiu społecznym i w tym także przejawia się jej kolejny paradoks - chodzi bowiem o napięcie pomiędzy tendencjami użytkowymi, aspirującymi do szerokiego oddziaływania na masową publiczność, a zarzutami o zbytnie wykoncypowanie intelektualne, o bycie sztuką elitarną. Nie chodzi o rozwiązywanie tej dychotomii; ważne jest, że obie te perspektywy zakładają niesamodzielność dzieła, poszukiwanie jego istoty, „uzupełnienia" poza nim. To ważne, ponieważ przedmiotem analizy są komentarze

6 Posługując się terminami „nowoczesności”, „nowości” czy „awangardy”, nie sposób pokazać tu choćby całej złożoności terminologicznej, a jednocześnie kategorie te należy doprecyzować. Posługiwał się będę teoriami ahistorycznymi, które przesuwają akcent z problematyki periodyzacji na problemy jakościowe, odwołując się przy tym głównie do koncepcji Ástrádura Eysteinssona i Theodora W. Adorno. Zob. A. Eysteinsson, Awangarda jako/czy modernizm?, tłum. D. Wojda, [w:] Odkrywanie modernizmu. Przekłady i komentarze, red. R. Nycz, Kraków 2004; T.W. Adorno, Teoria estetyczna, tłum. K. Krzemieniowa, Warszawa 1994. 
autorskie, które stają się strategią komunikacyjną samego autora. Dzięki temu wydają się odbiorcy autentyczne, najbardziej odpowiednie do wyjaśniania sensów dzieła sztuki.

Jednocześnie samo dzieło staje się jednym z elementów procesu, który doprowadził do powstania przełomu - zostaje uznane za wyjątkowe, obrasta recepcją, „legendą” właśnie - bądź to ze względu na komunikowane sensy, bądź też z uwagi na swoją konstrukcję formalną. Jednak przełom ten jest związany nie tylko z samym dziełem, ale również ze sposobem jego komunikowania, często definiowanym w autokomentarzu. Tym samym artysta stać się może bardziej interesujący niż dzieło, które domaga się odautorskiego uzupełnienia. Odbiorca bowiem jest postawiony wobec otwartości artefaktu, skierowanego głównie do jego kompetencji. Dlatego szuka w samym artyście - w ujawnianych przez niego komunikatach na temat genezy, znaczeń, odwołań, inspiracji itd. - pomocy w odbiorze, w odczytywaniu sensów.

Jeszcze jeden istotny aspekt sztuki nowoczesnej jest ważny przy omawianiu konstrukcji artysty jako tekstu. Chodzi mianowicie o tendencje, które można określić jako asemiotyczne. Sztuka nowoczesna (w niektórych jej nurtach) oprócz dążenia do dematerializacji wprowadza również nowe operowanie sensem. Awangardowe, nowoczesne (w zamyśle takie, jakich jeszcze dotąd nie było) dzieła programowo zakwestionowały możliwość dotarcia do sensów. Otwartość interpretacyjna zostawia odbiorcy tak szerokie pole do interpretacji, że odczytanie sensów przestaje być głównym zadaniem czytelnika czy widza, co Roland Barthes nazwał swego czasu „przyjemnością tekstu"7. Wspomniane już tendencje artystyczne (wśród nich performans) wzmocniły rozpowszechnienie się konwencji, w której „materialność dominuje nad znakowością"». Oczywiście nie oznacza to przekreślenia komunikacji, lecz wprowadza jej nowy aspekt.

Wszystkie opisane komplikacje składają się na nowoczesną konstrukcję artysty jako tekstu. Po rozpoznaniu elementów składowych tej konstrukcji należy skupić się nad sposobami badania i odczytywania legendy artystycznej.

7 R. Barthes, Przyjemność tekstu, tłum. A. Lewańska, Warszawa 1997.

8 E. Fischer-Lichte, Estetyka performatywności, tłum. M. Borowski, M. Sugiera, Kraków 2008. 


\section{GŁÓWNE ZAŁOŻENIA METODY}

Podstawowym problemem metodologii badania artysty jako tekstu jest dostosowanie narzędzi do przedmiotu badań. Konstrukt artysty-tekstu jest tworem niematerialnym, istniejącym jako tekst kultury, dyskurs na temat danego artysty, prądu itd. Nie tylko zmiennym, ale i kształtowanym zarówno przez samego artystę, jak też różne elementy recepcji. Dyskurs może dotyczyć równie dobrze samego dzieła, które weszło do recepcji jako „słynne” - traktowane jako doniosły artefakt - jednak zawsze pozostaje związane z osobą artysty. Istotny jest tutaj element „sławy” czy sukcesu danego dzieła i samego twórcy, owa sława świadczy bowiem o dwóch ważnych elementach. Po pierwsze, istnieje publiczność, która umie odbierać dane dzieło (wraz z osobą jego twórcy) i właśnie w taki sposób chce je odczytywać. Po drugie, recepcja - rozumiana tutaj jako utrwalony sposób odbioru - dowodzi również wytworzenia się sposobu mówienia o takim konstrukcie. Dobrym przykładem może być tutaj chociażby Umarła klasa Tadeusza Kantora, spektakl niezwykle silnie związany z osobą twórcy, w utrwalonej, potocznej recepcji odczytywany jako biograficzny. I choć akurat w przypadku tego przedstawienia autor otwarcie dążył do operowania uniwersalnością, to jednak grał w komentarzach napięciem pomiędzy indywidualizacją i uniwersalnością.

Do badania takiego konstruktu najbardziej oczywiste byłyby narzędzia wypracowane na gruncie performatyki, w metodzie badań artysty jako tekstu uwzględnia się przecież jej główne założenia. Artysta jako tekst to struktura niematerialna, to zachowanie, które stanowi przecież główny przedmiot badań performatyków. Ten konstrukt spełnia też główne założenia performansu sformułowane przez Marvina Carlsona. Są to, po pierwsze: element upublicznienia (postać artysty staje się ucieleśnieniem, materializacją ikoniczną własnego dyskursu komunikowaną w mediach komunikowaną już jako komentarz do dzieła - a więc mającą odbiorców), po drugie - twórca odtwarza tutaj jakąś konwencję zachowania ${ }^{9}$. Zachowane

9 M. Carlson, Performans, tłum. E. Kubikowska, Warszawa 2007. 
zachowanie ${ }^{10} \mathrm{w}$ tym przypadku jest bliskie dominancie, jaka charakteryzuje legendę artystyczną ${ }^{11}$.

Artysta performuje sensy swojego dzieła, stwarza konstrukt, w którym jego realna osoba (najczęściej materialnie i ikonicznie uobecniona dzięki mediom) łączy się z dziełem sztuki. Nie chodzi oczywiście o materialny artefakt, ale de facto o performatywne uobecnienie, ucieleśnienie recepcji dzieła (prądu estetycznego itd.) w postaci artysty obecnego w czasie wystąpienia medialnego. Dobrym przykładem są tutaj „fascynacje czytelnicze”, które Krystian Lupa omawia w swoich dziennikach, stanowiące wyraźną wskazówkę do interpretacji literackiego pierwowzoru przedstawienia.

Co więcej, artysta dokonuje tego wobec uczestników - zgodnie z terminologią performatywną. Odbiorcy są bowiem, z jednej strony, nosicielami legendy, obcują ze „sławnym” autorem, przełomowym, kultowym itd. Istotny jest tutaj element dominanty, będącej podstawą budowy legendy artystycznej $^{12}$. To oczywiście sytuowałoby widzów w pozycji uczestnika. Drugim elementem jest przynależność „fanowska”"13. Oznacza to, że odbiorcą wystąpienia medialnego jest odbiorca dzieła sztuki, widz lub czytelnik zdolny odczytać kod dzieła sztuki, konwencji, prądu itd. Kolejnym elementem uczestniczenia jest wreszcie wysiłek odbiorcy, który musiał podjąć (realną) aktywność w zdekodowaniu dzieła. Jednocześnie odbiorca przekracza pozycję zwykłego widza, co dowodzi, że jest odbiorcą właśnie wystąpienia medialnego - a więc dodatkowego elementu, poza dziełem sztuki. Tym samym potwierdza on swój wysiłek.

Jednak tradycyjna performatywna „pętla feedbacku”"14 nie może być tutaj wystarczająca do pełnego zrozumienia funkcji odbiorcy (to określenie

${ }_{10}$ Termin Richarda Schechnera. Zob. R. Schechner, Performatyka. Wstęp, tłum. T. Kubikowski, Wrocław 2006. W ujęciu Schechnera „zachowane zachowanie" oznacza ludzkie zachowania, działania człowieka, poprzez które możliwe jest przekazanie (a także odczytanie) sensów.

${ }^{11}$ A.Z. Makowiecki, Trzy legendy literackie. Przybyszewski, Witkacy, Gałczyński, Warszawa 1980.

12 Ibidem.

${ }_{13}$ M. Molęda-Zdziech, Czas celebrytów. Mediatyzacja życia publicznego, Warszawa 2013.

14 E. Fischer-Lichte, op. cit. 
będzie bardziej adekwatne w opisywanej metodzie). Lawrence Grobel pisał już, że to uczestnictwo pozorne, że ostatecznie taki odbiorca jest jedynie odbiorcą medium, odbiorcą sekundarnym (zgodnie z teoriami retoryki) ${ }^{15}$.

Czemu więc artyści korzystają z wielu zaproszeń medialnych? Dlaczego i po co wielokrotnie performują konstrukt siebie? Ich celem nie jest bowiem performowanie, wydarzenie - choćby i medialne. Punktem dojścia jest tutaj właśnie niematerialny konstrukt, do powstania którego doprowadza seria performansów, będący wynikiem oczekiwanego i potwierdzanego (a więc niestwarzanego w samym akcie) wydarzenia. Dlatego właśnie potrzebna jest metoda utekstowienia performansu. Dzięki takiemu ujęciu niematerialny performans może być traktowany jako opowieść. Wydarzenie, które jest nieobecne, spełnia się w interakcji z odbiorcą, nadal funkcjonuje, staje się przedmiotem odniesienia, a nawet źródłem cytatów, zapożyczeń, aluzji i odwołań. Dlaczego? Ponieważ może być traktowane jako tekst. Oczywiście tekst, który jest nieustannie potwierdzany, stwarzany na nowo, performowany w kolejnym akcie uobecnienia, przy udziale widza.

Oczywiście, metodzie artysty jako tekstu można zarzucić eklektyzm. Łączy ona bowiem różnorodne sposoby badań, jednak wykorzystuje te narzędzia w nowym celu. Jej istotą jest możliwość zbadania performansu jako zespołu tekstów, a w konsekwencji - jako tekstu, na który składa się dzieło sztuki, komentarz artysty (będący często pokaźnym zbiorem wypowiedzi medialnych) i sama osoba twórcy.

To jest właśnie novum. Performowanie siebie, bardzo silny akt autokreacji, konstruowanie legendy artystycznej jest możliwe do analizy właśnie poprzez zgromadzenie korpusu tekstów. Ten zbiór jest szeroki, ponieważ uwzględnia nie tylko pisma, teksty, komentarze itd.; w jego zakres wchodzą różnorodne wypowiedzi ustne, materiały wizualne, audiowizualne, hipertekstowe, a nawet świadectwa i zapisy recepcji. Dodatkowym atutem jest również to, że w skład owego zbioru tekstów wchodzą materiały gotowe - zredagowane, poprawione, edytowane itd. - noszące na sobie silne i ewidentne (często manifestowane wprost) piętno intencji autorskich (a z pewnością sugerujące „autentyczność). Zaliczają się tutaj również elementy przypadkowe, spontaniczne, improwizowane, a także te, które zostały

15 L. Grobel, Sztuka wywiadu. Lekcje mistrza, tłum. E. Spirydowicz, Warszawa 2006. 
przefiltrowane przez osobowość redaktora (rozmówcę, autora wywiadu bądź wstępu czy osoby, która spisała wypowiedź) - bardzo często powielającego dyskurs wykreowany przez artystę; one też są bardzo ważnym świadectwem recepcji. W tym ujęciu recepcja rozumiana jest jako sposób mówienia o danym artyście, o danym dziele. Dobrym przykładem jest określenie mianem „Wściekłego duetu” tandemu Moniki Strzępki i Pawła Demirskiego.

Takie podejście zbiega się z tendencjami w nowoczesnej genetyce tekstowej. Jednakże, w przeciwieństwie do tej metody, nie chodzi o zgromadzenie przed-tekstu $^{16}$ i późniejszej jego analizy. Celem metody genetycznej jest odtworzenie procesu twórczego, etapów tworzenia tekstu (i oczywiście przypisanie mu sensów). Dzięki poszczególnym elementom diachronii generowane są dodatkowe sensy, a przede wszystkim zbliżamy się do poznania ostatecznego kształtu utworu.

W metodzie artysty jako tekstu istotną rolę odgrywa przede wszystkim aspekt synchroniczny. Jej celem jest pokazanie złożoności intertekstualnej pomiędzy dziełem, komentarzem a osobą artysty. Wiele elementów z realnej (bądź komunikowanej w mediach jako realnej) biografii odsłania sam twórca, co jest silną sugestią autentyczności. Dzięki tej metodzie możliwe jest deszyfracja i materialne osadzenie performatywnych dzieł w sieci znaczeń: odtąd każdy tekst kultury możliwy jest do odczytania poprzez analizę performansów związanych $\mathrm{z}$ nadawaniem mu sensów w procesie recepcji. Tym samym autorski dyskurs wchodzi w relacje międzytekstowe $\mathrm{z}$ utrwaloną recepcją (i jej odmianami - popularną, naukową itd.).

Celem metody nie jest (jak w przypadku genetyki tekstu) analizowanie procesu twórczego. Badacz bądź odbiorca staje przed koniecznością ułożenia tekstów w relacje intertekstualne. To od niego zależy kształt korpusu tekstów, relacji międzytekstowych. W konsekwencji odbiorca nie tylko decyduje o sensach dzieła, ale jego rolą jest przede wszystkim przygotowanie elementów do analizy. Rolą odbiorcy jest więc ułożenie tekstów w relację międzytekstową. Wartością tej metody jest to, że można ją użyć do interpretacji różnorodnych materiałów - tekstowych, ikonicznych, multimedialnych, hipertekstowych, rękopiśmiennych, archiwalnych etc. Dodatkowo, jak wspomniałem, to odbiorca decyduje o tym, czy sensy zostaną przypisane

${ }_{16}$ P.-M. de Biasi, Genetyka tekstów, tłum. F. Kwiatek, M. Prussak, Warszawa 2015, s. 51. 
tekstom jedynie autorskim, czy też uwzględnione zostaną ślady recepcji. Odbiorca bowiem decyduje nie tylko o sensach, ale także o rodzaju materiałów i tekstów kultury użytych do interpretacji dzieła. Tym samym metoda badania artysty jako tekstu pozwala na badania interdyscyplinarne, polisemiotyczne, dzięki czemu możliwe jest badanie różnego rodzaju dziedzin twórczości, artystów z różnego zakresu działalności. Tym samym metoda ta pozwala na dostrzeżenie elementów dyskursu autorskiego w wypowiedziach niezdefiniowanych jako autokomentarze; w konsekwencji może być pomocna w uchwyceniu dyskursu danego twórcy poprzez analizę jego strategii komunikacyjnej.

Opisywana metodologia umożliwia krytyczne spojrzenie na legendy artystyczne. Dzięki niej możliwe jest analizowanie znaczenia tej legendy dla twórczości - zarówno antecedencji dzieła danego twórcy, jak i jego następstw. Ponadto możliwa jest krytyczna analiza legendy artystycznej, jej interpretacja i zdefiniowanie sensów znacznie wykraczających poza ramy samego artefaktu.

\section{SELEKCJA MATERIAŁU DO ANALIZY}

Pierwszym problemem jest kwestia, jakiego rodzaju legendy nadają się do badania tą metodologią. Czy bowiem legenda artystyczna dotyczy dzieła sztuki, czy też jego autora? Do zastosowania tej metody w naturalny sposób predysponowani są twórcy sztuk wizualnych, którzy swój wizerunek, ikoniczną obecność, szczególnie mocno manifestują w swoich dziełach.

Jednak metodę tę można również wykorzystywać w odniesieniu do pisarzy. W tym przypadku bowiem ikoniczny intertekst staje się kolejnym wyzwaniem dla odbiorcy. Tutaj to on tworzy linię relacji międzytekstowych. Zadaniem publiczności jest wyznaczenie (bądź odrzucenie) linii znaczeń pomiędzy ikoniczną obecnością autora w mediach a jej brakiem w tekście literackim. Pozwala zobaczyć, czy i na ile zwiększa i zwielokrotnia to sensy utworu.

Wartością zastosowania opisywanej metody w odniesieniu do pisarzy może być potraktowanie instancji nadawczej jako kategorii ambiwalentnej. Sukces artystyczny, czy może precyzyjniej - szeroka, pozytywna recepcja, spełnia tutaj analogiczną rolę, co funkcja kategorii późności, wielokrotnie opisywanej przez badaczy - m.in. Tomasz Wójcik w Późnej twórczości wielkich poetów przytacza tezy wielu autorów opisujących ostatnią fazę 
twórczości uznanych artystów. Diagnozy te pokazują, że dochodzi tu do przekroczenia „podmiotu lirycznego” lub innej instancji nadawczej ${ }^{17}$. Z drugiej strony nowoczesna twórczość artystyczna właśnie tym się charakteryzuje, że przekraczanie granicy dzieła sztuki spoczywa w dużej mierze na artyście, który chce odbiorcy zakomunikować sugestię bezpośredniości, sytuację, kiedy w akcie percepcji dzieła sztuki nie uczestniczy instancja pośrednicząca, a cały komunikat wypowiadany jest w imieniu artysty.

Nowoczesne tendencje artystyczne zmierzały właśnie w kierunku przekraczania instancji nadawczych w dziele. W sztukach wizualnych jest to najistotniejsze. Stopniowe rozpowszechnianie się konwencji, w której materiałem artystycznym jest ciało artysty, jego wrażliwość, autentyczne doświadczenie itd., doprowadziło do komunikacji, w której naturalne stało się odbieranie dzieła bez pośrednictwa tworów komunikujących.

W teatrze tendencje, by aktor wnosił na scenę siebie, stopniowo zyskiwały na znaczeniu. Dwudziestowieczna kategoria „nie-grania”, problematyka amatorów czy w konsekwencji występy aktorskie (w spektaklu) pod własnym imieniem i nazwiskiem doprowadziły również do zatarcia granicy pomiędzy fikcją artystyczną a realnością dzieła sztuki. W literaturze rozwijać zaczęły się gatunki wywodzące się z eseistyki, czemu towarzyszył (stwierdzony już wielokrotnie) wielki rozkwit intymistyki. Przemiany narratora, mające swój rodowód w naturalizmie, doprowadziły do powstania zeseizowanej prozy, kiedy to narrator przekracza swoją funkcję, wprost sugerując, że wypowiedź jest pisana przez samego autora, że są oni ze sobą tożsami.

To ważne, ponieważ w metodzie artysty jako tekstu sugestie bezpośredniego komunikatu stają się elementem, który może zostać użyty w procesie gromadzenia korpusu tekstów, zbierania i ustanawiania znaków, z których odczytywana będzie interpretacja. Dzięki temu możliwe jest odczytywanie legendy artystycznej w jej performatywnym wymiarze, a jednocześnie jej krytyczna interpretacja.

Opisywana metodologia ma również zastosowanie w sytuacji odwrotnej: przydatna jest w badaniach nad kulturą popularną, zjawisko celebrytyzmu jest bowiem doskonałym materiałem, do rozpoznawania którego nadaje się metoda badawcza artysty jako tekstu.

17 Zob. T. Wójcik, Późna twórczość wielkich poetów. Dramat formy, Warszawa 2005. 


\section{Z CZEGO DOKŁADNIE SKŁADA SIĘ KOMUNIKAT?}

Dzięki narzędziom wypracowanym na gruncie performatyki możliwe jest dokładne opisanie zjawiska będącego podstawą do analizy. Głównym problemem opisywanej metody, a jednocześnie jej celem, punktem dojścia, jest rozwiązanie paradoksu polegającego na tym, że o twórczości danego artysty publiczność mówi językiem tegoż. Dotyczy to zarówno odbiorców naiwnych, jak i profesjonalnych. Siła dyskursu i zasięg jego oddziaływania jest dowodem na istnienie struktury artysty jako tekstu.

Istotą metody badawczej jest dotarcie do tego, co tak naprawdę performują twórcy. Przede wszystkim starają się wytworzyć linię odczytywania własnej twórczości. Wobec widzów stwarzają sugestie możliwości dotarcia do sensów dzieła. Bardzo ważnym aspektem jest także wykreowanie poczucia nowości. Dzieło sztuki, które wzbudza zainteresowanie medialne, jest nowatorskie, a tym samym aury nabiera jego autor. Nowością może być też wyłom w konwencji, zmiana sposobu postrzegania zjawisk zarówno artystycznych, jak i tych lokujących się poza sztuką. Stąd tak silnym elementem wymagającym performowania jest skandal. Urzeczywistnianie, uobecnianie skandalu jest właśnie elementem, w którym widać strategię performowania siebie. Głównym elementem zbieżnym pomiędzy performatyką a artystą jako tekstem jest właśnie pogranicze realności i kreacji. Istotą zaś tej metody jest możliwość krytycznej analizy omawianego konstruktu i jednocześnie uczestniczenia w nim. Bliskie jest to współczesnej refleksji nad intymistyką. Już Małgorzata Czermińska stwierdziła, że nowoczesna refleksja nad autobiografią bada nie prawdziwość tekstu, ale jego znaczenia ${ }^{18}$, a tym samym doprowadza do utekstowienia autobiografii.

Podobnie jak w przypadku tworzenia zbioru materiałów przez odbiorcę, także tutaj istotna jest decyzja badacza - do której kategorii zakwalifikuje on dane zjawisko. Może być w pełni uczestnikiem wydarzenia performowanego przez twórcę, a zarazem je krytycznie analizować. Tym samym badacz porusza się między dwiema sferami. Dostrzega jakość perfomansu - jego przedmiot, a także sposoby oddziaływania na widza. Jednocześnie dzięki analizie możliwe jest wykorzystanie czy odczytywanie podobnych chwytów

18 M. Czermińska, Autobiografia i powieść, czyli pisarz i jego postacie, Gdańsk 1987. 
również w innych przypadkach. Badacz na podstawie swojego zespołu przesłanek rekonstruuje sposób performowania.

Dzięki temu owe schematy, „zachowane zachowania”, nie tylko stają się możliwe do powtórzenia - to naturalne, ale stają się także elementami języka, który jest możliwy do dekodowania. Urzeczywistnianie legendy pozwala na odczytywanie sposobu performowania, a w konsekwencji na dostrzeganie nadawania znaczeń - zarówno legendzie, jak i mechanizmom łączenia osoby autora ze znaczeniami, jakie chce zasugerować. Judith Butler zaznaczyła, że każda wypowiedź performatywna jest „cytowaniem”19 jakiejś konwencji wypowiedzi. Dlatego możliwe jest odczytywanie sensów poprzez dominantę, styl performowania. Jednocześnie takim zachowaniom możliwe jest przypisanie sensów, utekstowienie ich.

Metoda artysty jako tekstu służy do badania tekstu płynnego, którego tekstowość jest niepewna, performatywnie zmieniana, konstytuowana i potwierdzana. Metodą tą można badać performans jako tekst i jednocześnie tekst jako performans. Nowością jest analiza zapisów performansów i badanie możliwości zapisywania performansu w formie tekstowej. Według tej metody badane mogą być teksty i artyści, którzy samokreują zarówno swoją twórczość, jak i komentarz do niej. Jednocześnie to narzędzie umożliwiające analizę dyskursów recepcji kreowanych przez odbiorców - publiczność, jak też krytyków i media.

\section{Bibliografia}

Theodor W. Adorno, Teoria estetyczna, tłum. K. Krzemieniowa, PWN, Warszawa 1994.

Dominik Antonik, Autor jako marka. Literatura w kulturze audiowizualnej społeczeństwa informacyjnego, TAiWPN Universitas, Kraków 2014.

Roland Barthes, Przyjemność tekstu, tłum. A. Lewańska, Wydawnictwo KR, Warszawa 1997.

Walter Benjamin, Dzieło sztuki $w$ dobie reprodukcji technicznej, [w:] idem, Aniol historii. Eseje, szkice, fragmenty, wyb. i oprac. H. Orłowski, tłum. K. Krzemieniowa, H. Orłowski, J. Sikorski, Wydawnictwo Poznańskie, Poznań 1996.

19 J. Butler, Walczące słowa: mowa nienawiści i polityka performatywu, tłum. A. Ostolski, Warszawa 2010, s. 44. 
Pierre-Marc de Biasi, Genetyka tekstów, tłum. F. Kwiatek, M. Prussak, IBL PAN, Warszawa 2015.

Judith Butler, Walczace słowa: mowa nienawiści i polityka performatywu, tłum. A. Ostolski, Wydawnictwo Krytyki Politycznej, Warszawa 2010.

Marvin Carlson, Performans, tłum. E. Kubikowska, WN PWN, Warszawa 2007. Małgorzata Czermińska, Autobiografia i powieść, czyli pisarz i jego postacie, Wydawnictwo Morskie, Gdańsk 1987.

Ástrádur Eysteinsson, Awangarda jako/czy modernizm?, tłum. D. Wojda,

[w:] Odkrywanie modernizmu. Przekłady i komentarze, red. R. Nycz, TAiWPN Universitas, Kraków 2004.

Erika Fischer-Lichte, Estetyka performatywności, tłum. M. Borowski, M. Sugiera,

Księgarnia Akademicka, Kraków 2008.

Lawrence Grobel, Sztuka wywiadu. Lekcje mistrza, tłum. E. Spirydowicz,

Wydawnictwo Wojciech Marzec, Warszawa 2006.

Andrzej Z. Makowiecki, Trzy legendy literackie. Przybyszewski, Witkacy, Gałczyński,

Państwowy Instytut Wydawniczy, Warszawa 1980.

Małgorzata Molęda-Zdziech, Czas celebrytów. Mediatyzacja życia publicznego,

Difin, Warszawa 2013.

Magdalena Popiel, Świat artysty. Modernistyczne estetyki tworzenia, TAiWPN

Universitas, Kraków 2018.

Dorota Sajewska, Mit efemeryczności teatru, „Dialog” 2015, nr 1.

Richard Schechner, Performatyka. Wstęp, tłum. T. Kubikowski, Ośrodek Badań

Twórczości Jerzego Grotowskiego i Poszukiwań Teatralno-Kulturowych, Wrocław 2006.

Paweł Stangret, Artysta jako tekst. Nowoczesna sztuka metatekstu, WN UKSW, Warszawa 2018.

Tomasz Wójcik, Późna twórczość wielkich poetów. Dramat formy, Dom Wydawniczy Elipsa, Warszawa 2005.

\section{Performative Textuality, i.e. Methodology of Researching Artistic Legends}

The article is an explanation of the method of examining the modern phenomenon of linking the artist with a work of art. Such approach is most often the result of an attempt to control the reception of one's own creation, to create a discourse on one's own art. The title 'artist as a text' is a construction in 
which a work of art, self-commentary and elements of the artist's biography intertwine to create a network of relations between these different types of messages. This suggests a situation of a direct message, an impression that the viewer is communicating with the backstage of the creation of the work, and thus directly with the artist himself. This is especially important in modern art, which is programmatically innovative - to the extent that the recipient is faced with the necessity to create a way of reception. The applied method is mainly based on the example of theatrical artists (because they often place themselves in a work of art even iconically), but it can be useful for examining artists from other fields of art.

Keywords: artist, performative studies, avant-garde, modern art, new media 